\title{
Earthquakes in India
}

$\mathrm{T}$

HE presidential address delivered by $\mathrm{Mr}$. W. D. West to the Section of Geology and Geography at the recent meeting of the Indian Science Congress is an interesting summary of our knowledge on Indian earthquakes. It shows what careful investigations have been made of the earthquakes of the last forty years, including those of Mr. West himself on the Baluchistan earthquakes of 1931 and the
Severe earthquakes are practically unknown within it, but slight shocks are frequently felt in the extreme south, within the dotted band in Fig. 1. On two occasions (1930 and 1934), weak shocks have been felt in this band at almost the same instants as severe earthquakes in Northern India, and this coincidence Mr. West attributes to the strained condition of the peninsula.

The active Zone $\mathrm{I}$ is divided into five sections.

(1) Cutch, in which there has been only one great earthquake, that of 1819, when a dislocation about 90 miles in length was formed, the country to the north being uplifted by amounts ranging up to nearly 30 feet above the depressed country to the south.

(2) Baluchistan, in which the mountains are a southward branch of the great Tertiary system of which the Himalayas form a part. From the sea-coast to Quetta, their general direction is south and north, but, near Quetta, there is a sharp bend, the ranges then running towards the east and south-east. On a detailed map of this section, Mr. West outlines the epicentral tracts of fifteen earthquakes between 1852 and 1935 (five of which are shown in Fig. $1)$, and it is remarkable how all the stronger earthquakes occurred around the re-entrant angle. Only one of the earthquakes, that of 1892, was associated with a known fault, one that has been traced for 120 miles. If other Baluchistan earthquakes were similarly connected, the faults in question do do not seem to reach the surface.

(3) Northern India, with the
Quetta earthquake of 1935 (NATURE, 135, 661, 1935 ; $137,385-386,1926$.)

The whole country is divided into three zones (Fig. 1). The great earthquakes of India are entirely confined to Zone I, the southern border of the belt of Tertiary folding. The shaded areas within this zone represent the epicentral tracts, bounded roughly by isoseismal lines of intensity 9 of the Rossi-Forel scale (corresponding to the partial or total destruction of some buildings). The areas are those of all severe earthquakes since 1850 , with the addition of that of the Cutch earthquake of 1819. Zone II, the frontal trough of alluvium, is free from the epicentres of great earthquakes, but parts of it have suffered considerable damage from those occurring in the first zone. Unfortunately, as Mr. West remarks, these zones coincide with the most densely populated districts of India. Zone III, including the whole of Peninsular India, is one of comparative safety. two great earthquakes of Kangra
in 1905 and North Bihar in 1934. Both earthquakes disturbed very large areas, and, as in the majority of those felt in Baluchistan, neither can be assigned to any definite fault or system of faults.

(4) Assam, with three great earthquakes since 1850: the Cachar earthquake of 1869 , the first Indian earthquake to be investigated on modern scientific lines, the Assam earthquake of 1897, one of the greatest of all known earthquakes, and the Dhubri earthquake of 1930 ; as well as two others of less note, the Bengal earthquake of 1885 , and the Srimangel earthquake of 1918. The Assam earthquake was remarkable in many respects-the sudden. ness with which it began, the extreme intensity of the shock over a large area, the variations of intensity from one place to another, the faults along which movements occurred, including the Chedrang fault with its maximum throw of $\mathbf{3 5}$ feet, the general upheaval of the country, and the remarkable series 
of after-shocks; all these features pointing to a complicated origin covering a large area.

(5) Burma, divided into three main structural units-the Shan plateau (A, Fig. 2), consisting of rocks of Mesozoic and older ages, the Tertiary basin of the Irrawaddy valley (B), and the range of the Arakan Yoma of late Mesozoic and early Tertiary times (C). They are separated by zones of faulting, with which many of the epicentres of Burmese earthquakes are associated, especially those of the destructive earthquakes of 1839 and 1858, the former near Mandalay and the latter near Thayetmyo and Prome. During the years 1929-31, there was a remarkable series of eight earthquakes, the epicentres of which, numbered in the order of occurrence in Fig. 2, are marked by a linear arrangement close to the eastern fault.

Most of the Indian earthquakes of the last forty years have been investigated by officers of the Geological Survey of India, yet it must be admitted that the state of seismological research in the country is behind that in some other lands. In Japan there are a hundred and five seismological observatories, in the United States forty-two, but in India only six, and not one official devoted entirely to seismological subjects. Mr. West suggests that the work done more or less independently by the Geological Survey, the Meteorological Department and the Survey of India should be co-ordinated and expanded by founding what would practically be an Earthquake Research Institute with its headquarters, say, at Shillong, provided with many now instruments for stations new and old, and with officers who, after a great earthquake, should at once proceed to the central area and establish round it a network of temporary stations in order to determine the epicentres and focal depths of the after-shocks. C. D.

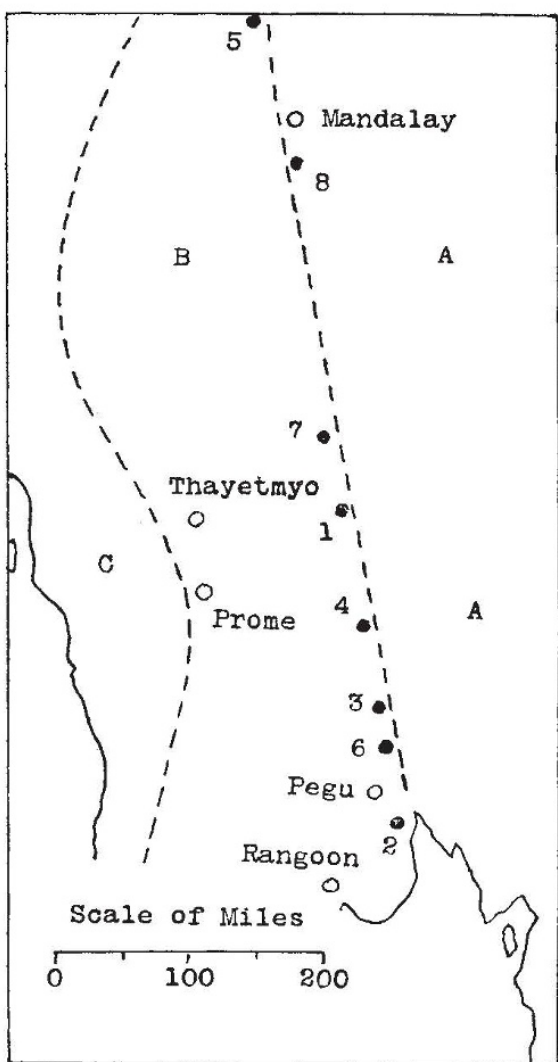

Fig. 2.

Distribution OF EaRthQUakes IN BuRMa.

\section{Incidence and Causes of Stammering}

$S^{\mathrm{T}}$ TAMMERING is one of those abnormalities sufferers from which fall between two stools. It is scarcely the concern of the family doctor, and yet is outside the scope of ordinary educational methods. Of recent years, psychological treatment has helped many individuals to cope with speech disabilities, but it commonly happens that more time and expense are called for in the achievement of a cure on these lines than stammerers are able to give, and so for one reason or another it usually falls to the lot of the individual stammerer to cure himself.

It is with special reference to some interesting figures supplied by the Stammerers' Club of New South Wales* that this short commentary on an important subject is given; as the result of questionnaires sent out to the members this Club has elicited most interesting information.

Whilst in most instances of stammering there is actual physical disability of some kind, nevertheless, for the most part the trouble is to be found in a constitutional nervousness or sense of inferiority. From the statistics from New South Wales, it is noteworthy that although serious illness is actually

* Stammering : its Canse and Cure. (The Handbook of the Stam merers' Club of New South Wales.) Pp. 72 . (Sydney : Stammerers" Club of N.S.W., n.d.). credited with nine per cent in the list of causes, no definite physical disease is said to have any serious influence. The cause of stammering generally is attributed to such psychological causes as shock, imitation, fright and being bullied or laughed at. In all these, it is evident that individual nerve sensitiveness or feeling of inferiority is the chief underlying trouble. That this nerve weakness is often inborn seems to be emphasized by the fact that in no less that fifty-one per cent of the instances dealt with the stammerer began before the age of five years, and no less than ninety-three per cent experienced the onset before the age of ten. Granted that unfortu nate conditions in upbringing produced such psychological disturbance as to impair capacity for normal speech, it certainly cannot be held that all these stammerers were born with strong nerves or the capacity for developing sound defences against the stresses of life.

As regards position in family, it does not seem to matter whether one is born early or late if one is to experience the disadvantage of stammering; it is true that there is the difference between thirty-eight per cent as regards 'elder' children and twenty-five per cent as to 'youngest', but as the 'intermediate' 